\title{
Pengaruh Konsentrasi Asam Terhadap Sifat Fisik dan Muatan Permukaan Selulosa Termodifikasi
}

\author{
Agus Wedi Pratama ${ }^{a, b}$, Bambang Piluharto $^{a, b, c^{*}}$, Dwi Indarti ${ }^{c}$, Tanti Haryatic ${ }^{c}$ \\ Hardian Susilo Addy ${ }^{a, b, d}$ \\ ${ }^{a}$ Program Studi Bioteknologi, Universitas Jember, Jl. Kalimantan 37 Kampus Tegal Boto, Jember 68121 \\ Telp. (0331) 323567 \\ ${ }^{b}$ Center for Development Advanced of Sciences and Technology (CDAST), Universitas Jember, Jl. \\ Kalimantan 37 Kampus Tegal Boto, Jember 68121 Telp. (0331) 321825 \\ c Jurusan Kimia, Fakultas Matematika dan Ilmu Pengetahuan Alam (FMIPA), Universitas Jember, Jl. \\ Kalimantan 37 Kampus Tegal Boto, Jember 68121 Telp. (0331) 334293 \\ ${ }^{d}$ Jurusan Agroteknologi, Fakultas Pertanian, Universitas Jember, Jl. Kalimantan 37 Kampus Tegal Boto, \\ Jember 68121 Telp. (0331) \\ * Corresponding author \\ E-mail: bampito.fmipa@unej.ac.id
}

DOI: 10.20961/alchemy.15.2.33756.315-328

Received 12 Agustus 2019, Accepted 14 September 2019, Published 30 September 2019

\begin{abstract}
ABSTRAK
Selulosa merupakan salah satu biopolimer melimpah yang banyak digunakan dalam berbagai bidang seperti kertas, energi dan material komposit. Hidrofilisitas, dapat diperbaharui, ramah lingkungan dan aman adalah sifat-sifat selulosa yang dapat mendukung selulosa menjadi material maju. Berdasarkan sifat-sifatnya, selulosa dapat dimodifikasi untuk menghasilkan sifat fungsional yang sesuai dengan aplikasinya. Dalam penelitian ini, selulosa mikrokristalin (MCC) dimodifikasi melalui metode hidrolisis asam. Prinsip metode ini adalah penghilangan bagian amorf pada selulosa oleh asam, meninggalkan bagian kristal. Selain itu, ketika asam digunakan sebagai agen hidrolisis, maka akan menghasilkan muatan permukaan pada selulosa. Dalam penelitian ini, pengaruh berbagai konsentrasi asam pada struktur kimia, kristalinitas, morfologi dan muatan permukaan telah dikaji. Perubahan struktur selulosa dianalisis menggunakan Fourier Transform Infra Red (FTIR), kristalinitas menggunakan X-ray Diffraction (XRD), morfologi menggunakan Scanning Electron Microscopy (SEM) dan muatan permukaan menggunakan titrasi konduktometri. Hasil analisis FTIR menunjukkan masuknya gugus sulfat pada struktur selulosa. Analisis XRD menunjukkan peningkatan kristallinitas dalam selulosa termodifikasi seiring bertambahnya konsentrasi asam. Hasil analisis morfologi menunjukkan partikel dalam selulosa termodifikasi (CM) lebih tersebar daripada MCC. Analisis titrasi konduktometri menunjukkan bahwa mengalami peningkatan muatan permukaan pada CM seiring dengan bertambahnya konsentrasi asam. Oleh karena itu, dapat disimpulkan bahwa pengaruh konsentrasi asam sulfat pada hidrolisis selulosa memberikan dampak yang signifikan pada sifat fisik dan muatan permukaan.
\end{abstract}

Kata kunci: hidrolisis asam, kristalinitas, muatan permukaan, selulosa termodifikasi 


\begin{abstract}
Effect of Acid Concentration on Physical Properties and Surface Charge of Modified Cellulose. Cellulose is one of abundant biopolymer that many widely used in various applications such as paper, energy and composite material. Hydrophilicity, renewable, biodegradable, and safety are cellulose properties that can support the cellulose become an advanced materials. In the utilization, the properties of cellulose can be modified for different purposes. In this work, microcrystalline cellulose (MCC) was modified by acid hydrolysis method. The principle of this method is removing an amorphous region of cellulose by acid and leaving crystalline phase. Moreover, when acid was used as hydrolyzing agent, it produces the surface charge on cellulose. In this research, the effect of various concentration of acid on the chemical structure, crystallinity, morphology, and surface charge were studied. The chemical structures were analyzed using Fourier transform infrared (FTIR), crystallinity using X-ray Diffraction (XRD), morphology using scanning electron microscopy (SEM), and surface charge using conductometric titration. The FTIR analysis result has successfully shown the enrollment of sulfate groups on the cellulose structure. The XRD analysis showed the increasing crystallinity in cellulose modified (CM) with increasing acid concentration. The morphology analysis shows that the particles in CM more disperse than MCC. Analysis of conductometric titration shows that there is an increase in surface charge in $\mathrm{CM}$ as acid concentration increases. Therefore, the effect of sulfuric acid concentration on hydrolysis of cellulose provides a significant impact on physical properties and surface charge of modified cellulose.
\end{abstract}

Keywords: acid hydrolysis, crystallinity, modified cellulose, surface charge

\title{
PENDAHULUAN
}

Selulosa merupakan biopolimer paling melimpah di bumi yang dihasilkan dari proses fotosintesis dengan laju sekitar $1 \times 10^{12}$ ton/tahun (Klemm et al., 2011). Selulosa telah dikenal sekitar 150 tahun yang lalu dan merupakan polimer yang dapat diperbaharui, biodegradabel dan ramah lingkungan. Karena alasan itulah, selulosa banyak dimanfaatkan dalam berbagai bidang seperti kesehatan, konstruksi, makanan dan bidang lainnya. Dalam aplikasinya, perlu dilakukan modifikasi pada selulosa untuk mendapatkan sifat unggul sesuai yang diharapkan dalam pemanfaatan sesuai bidangnya.

Metode hidrolisis asam adalah salah satu metode modifikasi pada selulosa yang digunakan untuk mendapatkan selulosa dengan tingkat kristalinitas yang lebih tinggi dan menghasilkan selulosa yang bermuatan (Kovacs et al., 2010; Lee et al., 2014; Wulandari et al., 2016). Prinsip hidrolisis asam pada selulosa adalah penghilangan daerah amorf pada selulosa sehingga menghasilkan selulosa dengan porsi daerah kristalin yang lebih besar. Bersamaan dengan itu, dihasilkan selulosa yang bermuatan dari hasil masuknya asam ke dalam struktur selulosa pada proses reaksi sulfonasi (Lee et al., 2014). Faktor perubahan kristalinitas dan muatan ini memberikan sifat baru yang berbeda dengan selulosa awalnya (Yu et al., 2013; Tian et al., 2016).

Modifikasi selulosa secara hidrolisis asam telah banyak dilakukan dengan mengamati sifat fisik yang dihasilkan. Namun demikian, masih sedikit penelitian yang mengkaji muatan permukaan pada selulosa yang dimodifikasi secara hidrolisis asam. 
Padahal menurut Tian et al. (2016) salah satu faktor penting dalam modifikasi selulosa secara hidrolisis asam adalah terbentuknya muatan permukaan. Muatan yang terkandung pada selulosa akan memberikan sifat tertentu pada permukaan yang bermanfaat dalam aplikasi adsorpsi, enkapsulasi dan aplikasi biomedis lainnya. Muatan yang terbentuk pada proses hidrolisis tergantung pada jenis asam dan konsentrasinya.

Berbagai asam telah banyak digunakan untuk hidrolisis selulosa antara lain asam sulfat, asam klorida, asam format dan asam fosfat. Namun demikian, asam yang banyak digunakan dalam hidrolisis selulosa adalah asam sulfat (Bondenson et al., 2006; Ioelovich, 2012; Putri and Gea., 2018). Hal ini didasarkan pada kemudahan larut dalam suhu kamar, merupakan asam kuat dan mampu menghasilkan selulosa yang dapat terdispersi dalam air. Klemm et al. (2011) melaporkan bahwa hidrolisis selulosa menggunakan asam sulfat memiliki stabilitas koloid yang lebih tinggi dibanding hidrolisis menggunakan asam klorida. Selain itu, hasil hidrolisis menggunakan asam sulfat menghasilkan selulosa yang bermuatan negatif, sementara hidrolisis menggunakan asam klorida tidak memberikan muatan. Hasil hidrolisis selulosa menggunakan asam sulfat dengan rentang konsentrasi $45-65 \%(\mathrm{~b} / \mathrm{b})$, hasil yang diperoleh menunjukkan bahwa konsentrasi asam sulfat lebih dari 63\% dapat melarutkan selulosa dan derajat polimerisasi (DP) menurun dengan naiknya konsentrasi asam sulfat. Ukuran partikel selulosa hasil hidrolisis memiliki skala mikro ketika hidrolisis dengan konsentrasi asam sulfat kurang dari 50\%, sementara untuk konsentrasi lebih dari 50\% memiliki ukuran partikel dalam skala nanometer (Ioelovich, 2012).

Berdasarkan banyak karakter hasil hidrolisis selulosa mengunakan asam sulfat, ada satu karakter yang belum banyak dikaji adalah banyaknya muatan pada selulosa hasil hidrolisis. Masuknya gugus sulfat pada selulosa akan memberikan pengaruh pada perubahan struktur dan banyaknya muatan yang dihasilkan. Penelitian ini akan mengkaji pengaruh konsentrasi asam sulfat pada sifat-sifat selulosa hasil hidrolisis. Sifat-sifat selulosa hasil hidrolisis yang diamati meliputi perubahan struktur, banyaknya muatan, kristalinitas dan morfologinya.

\section{METODE PENELITIAN}

\section{Hidrolisis Selulosa}

Modifikasi selulosa dilakukan dengan metode hidrolisis asam mengikuti prosedur dari Ioelovich (2012) yang dimodifikasi. Pada penelitian ini, berbagai konsentrasi asam sulfat $(45,50$, dan $55 \%$ (b/b)) digunakan sebagai variabel penelitian. Sebanyak 10 g MCC 
direfluks dengan $100 \mathrm{~mL}$ asam sulfat pada suhu $50{ }^{\circ} \mathrm{C}$ selama 90 menit sehingga dihasilkan suspensi asam. Suspensi disentrifugasi pada $10.000 \mathrm{rpm}$ selama 10 menit pada $25^{\circ} \mathrm{C}$ untuk memisahkan dari fasa cairnya. Bagian supernatannya diukur $\mathrm{pH}$ nya menggunakan $\mathrm{pH}$ meter sementara bagian pelet ditambah aquades kembali dan disentrifugasi kembali hingga $\mathrm{pH}$ supernatan netral. Suspensi disonikasi selama 5 menit dalam penangas es kemudian disentrifugasi sampai dihasilkan supernatan dan pelet. Supernatan dipisahkan dari pelet, kemudian disentrifugasi kembali untuk menghasilkan endapan. Endapan yang dihasilkan dicuci menggunakan etanol, aseton, heksan secara berurutan. Endapan dikeringkan pada suhu $50{ }^{\circ} \mathrm{C}$ dan ditimbang sampai diperoleh berat konstan. (Ioelovich, 2012; Mandal and Chakrabarty, 2011).

\section{Scanning Electron Microscopy (SEM)}

Bentuk dan ukuran partikel di analisis menggunakan SEM (FEI, Type: Inspect-S50). Sebelum diamati, sampel dilapisi menggunakan lapisan emas. Hasil gambar SEM dianalisis ukuran partikelnya menggunakan aplikasi Image J. Diameter rata-rata partikel selulosa diperoleh dari pengukuran 5 partikel yang berukuran kecil dengan distribusi sampling pojok atas (kanan-kiri), pojok bawah (kanan-kiri) dan bagian tengah setiap gambar SEM sampel.

\section{Fourier Transform Infra Red (FTIR)}

FTIR digunakan untuk menganalisis struktur gugus fungsional baik pada selulosa sebelum dan sudah dimodifikasi. Spektra FTIR diperoleh dari FTIR Bruker Alpha dengan detektor RT-DLaTGS ZnSe dan di scan pada bilangan gelombang $500-4000 \mathrm{~cm}^{-1}$.

\section{X-Ray Diffraction (XRD)}

XRD digunakan untuk mengetahui pengaruh konsentrasi asam terhadap kristalinitas selulosa termodifikasi yang dihasilkan. Pengukuran kristalinitas menggunakan difraktometer (PanAnalytical, Type: E’xpert Pro) dengan radiasi $\mathrm{Cu} K \alpha$ pada 40 kV, 35 mA. Radiasi scatter terdeteksi di kisaran $2 \theta=5-40^{\circ}$ dan kecepatan $3 \%$ menit. Indeks kristalinitas (CrI) diperoleh sesuai dengan persamaan berikut.

$$
\mathrm{Crl}=\frac{\mathrm{I}_{002}-\mathrm{I}_{18^{\circ}}}{\mathrm{I}_{002}} \times 100 \%
$$

dimana $I_{002}$ adalah intensitas maksimum dari komponen kristalin (002) and $I_{18^{\circ}}$ adalah intensitas komponen dari daerah amorf pada $18^{\circ}$ (Maddahy et al., 2012).

\section{Titrasi Konduktometri}

Titrasi konduktometri dilakukan untuk mengukur muatan permukaan pada selulosa termodifikasi. Prosedur titrasi merujuk pada prosedur yang dilakukan oleh Romdhane et al. (2015). Sejumlah selulosa termodifikasi dicampur dengan larutan $\mathrm{NaCl} 1 \mathrm{mM}$ hingga 
mencapai volume $500 \mathrm{~mL}$, kemudian ditambahkan $5 \mathrm{~mL}$ larutan $\mathrm{HCl}$ 0,05 M. Larutan kemudian dititrasi dengan larutan $\mathrm{NaOH} 0,01 \mathrm{M}$ hingga terjadi kenaikan konduktivitas. Konsentrasi gugus muatan dihitung sesuai dengan persamaan berikut,

$$
-\mathrm{OSO}_{3}\left(\frac{\mathrm{mmol}}{\mathrm{kg}}\right)=\frac{\mathrm{Cx}\left(\mathrm{V}_{1}-\mathrm{V}_{0}\right)}{\mathrm{m}}
$$

dimana, $\mathrm{C}$ adalah konsentrasi larutan $\mathrm{NaOH}(\mathrm{mmol} / \mathrm{kg}), \mathrm{m}$ adalah massa kering sampel Selulosa termodifikasi $(\mathrm{kg}), \mathrm{V}_{0}$ adalah volume $\mathrm{NaOH}$ yang secara teoritis diperlukan untuk menetralkan asam bebas (L) dan $\mathrm{V}_{1}$ adalah volume $\mathrm{NaOH}$ yang dikonsumsi ketika mencapai titik persimpangan pertama.

\section{HASIL DAN PEMBAHASAN}

\section{Hidrolisis Selulosa}

Tabel 1 menunjukkan hasil fisik dan rendemen dari hidrolisis selulosa. Secara fisik, hidrolisis selulosa dengan berbagai konsentrasi asam sulfat (45, 50, dan 55\% (b/b)) memiliki hasil yang serupa yaitu serbuk putih. Akan tetapi, hidrolisis dengan asam sulfat $60 \%$ menghasilkan serbuk berwarna hitam. Hasil ini disebabkan dehidrasi dan karbonisasi ketika konsentrasi asam sulfat lebih tinggi dari $60 \%$ dan suhu lebih tinggi dari $60{ }^{\circ} \mathrm{C}$ (Ioelovich, 2012). Berikut reaksi karbonisasi pada selulosa:

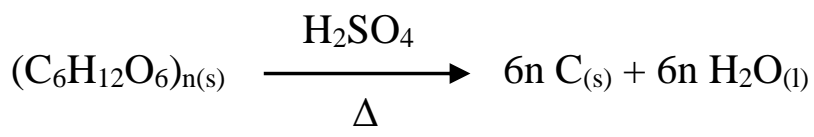

Berdasarkan Tabel 1 menunjukkan bahwa rendemen yang dihasilkan menampilkan tren menurun seiring dengan bertambahnya konsentrasi asam sulfat yang digunakan. Semakin besar konsentrasi asam sulfat membuat serbuk CM yang dihasilkan semakin sedikit. Hal ini dikarenakan semakin besar konsentrasi asam sulfat membuat semakin banyak daerah amorf pada selulosa yang dihidrolisis menjadi monosakarida yang dapat larut air sehingga akan menyisakan bagian kristallin yang semakin sedikit (Dong et al., 1998).

\section{Titrasi Konduktometri}

Hidrolisis menggunakan asam sulfat akan menjadikan selulosa yang dihasilkan bermuatan negatif akibat terjadinya sulfatasi (Lee et al., 2014). Reaksi sulfatasi merupakan reaksi masuknya gugus sulfat pada suatu senyawa. Gugus sulfat akan masuk pada permukaan selulosa dan membuat selulosa bermuatan negatif seperti pada Gambar 1 .

Titrasi konduktometri digunakan untuk mengukur jumlah gugus sulfat pada selulosa. Adanya gugus sulfat pada selulosa akan memberikan muatan negatif pada permukaan 
selulosa. Adanya muatan pada permukaan selulosa akan menambah keuntungan terhadap karakteristik selulosa dalam beberapa aplikasi seperti sebagai membran pertukaran kation (Piluharto et al., 2011), adsorben (Dong et al., 2016), pembawa obat (Kolakovic et al., 2012) dan filler komposit (Masruchin et al., 2015).

Tabel 1. Pengaruh konsentrasi asam sulfat terhadap sifat fisik selulosa

\begin{tabular}{|c|c|c|c|}
\hline *Sampel & Gambar & Keterangan & Rendemen \\
\hline CM 45 & & Serbuk halus berwarna putih & $76,9 \%$ \\
\hline CM 50 & & Serbuk halus berwarna putih & $69,8 \%$ \\
\hline CM 55 & & Serbuk halus berwarna putih & $13,7 \%$. \\
\hline CM 60 & & Serbuk halus berwarna hitam & $1,7 \%$. \\
\hline
\end{tabular}

*CM 45, CM 50, CM 55 and CM 60 merupakan sebutan untuk hasil selulosa termodifikasi dengan asam sulfat $45 \%, 50 \%, 55 \%$ and $60 \%$. 


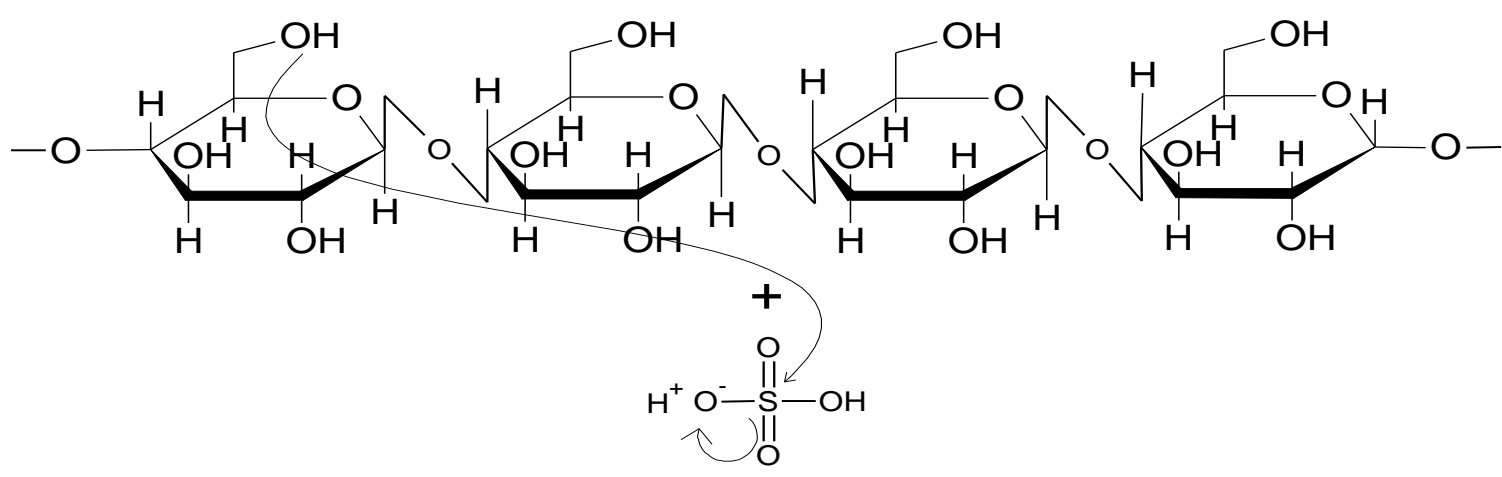<smiles>CC1CC1C=O</smiles>

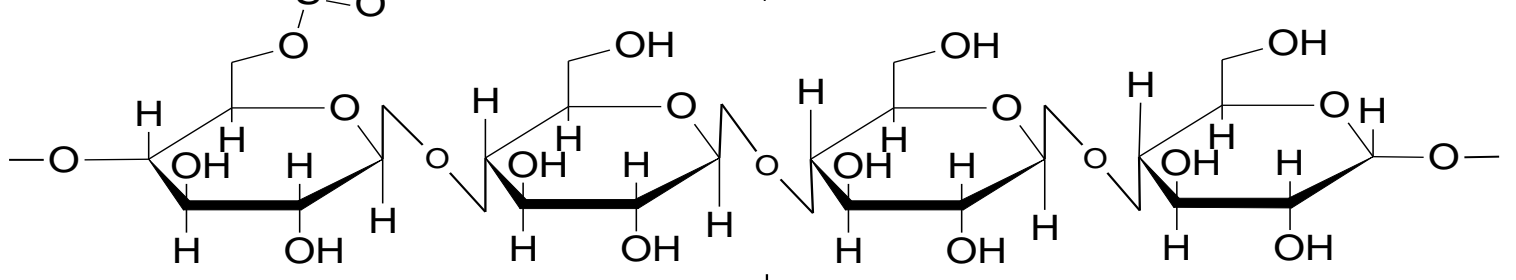

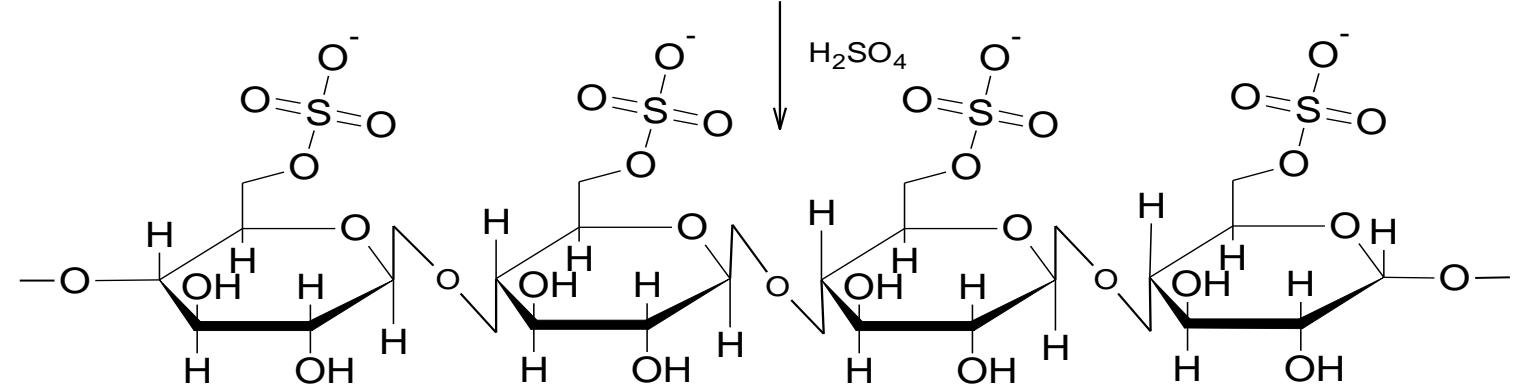

Gambar 1. Mekanisme reaksi sulfatasi pada selulosa (Lee et al., 2014).

Gambar 2a menunjukkan kurva titrasi konduktometri CM dengan konsentrasi asam yang berbeda, sementara Gambar $2 \mathrm{~b}$ menunjukkan jumlah kandungan $-\mathrm{OSO}_{3} \mathrm{H}$ pada $\mathrm{MCC}$ dan CM. Hasil analisis menunjukkan bahwa peningkatan konsentrasi asam menyebabkan peningkatan gugus muatan permukaan pada selulosa. Hidrolisis selulosa menggunakan konsentrasi asam 55\% (CM 55) mampu menambah jumlah gugus muatan hampir 7 kali dari selulosa awal dan tertinggi dari variasi konsentrasi lainnya. Hal ini dikarenakan semakin besar konsentrasi asam sulfat membuat semakin besar pula terjadinya reaksi sulfatasi pada selulosa sehingga semakin banyak pula muatan negatif pada selulosa termodifikasi yang dihasilkan (Lee et al., 2014). Adanya muatan pada MCC yang tidak terhidrolisis diperkirakan berasal dari pengotor karena ditinjau dari strukturnya MCC tidak memiliki gugus yang bermuatan. 

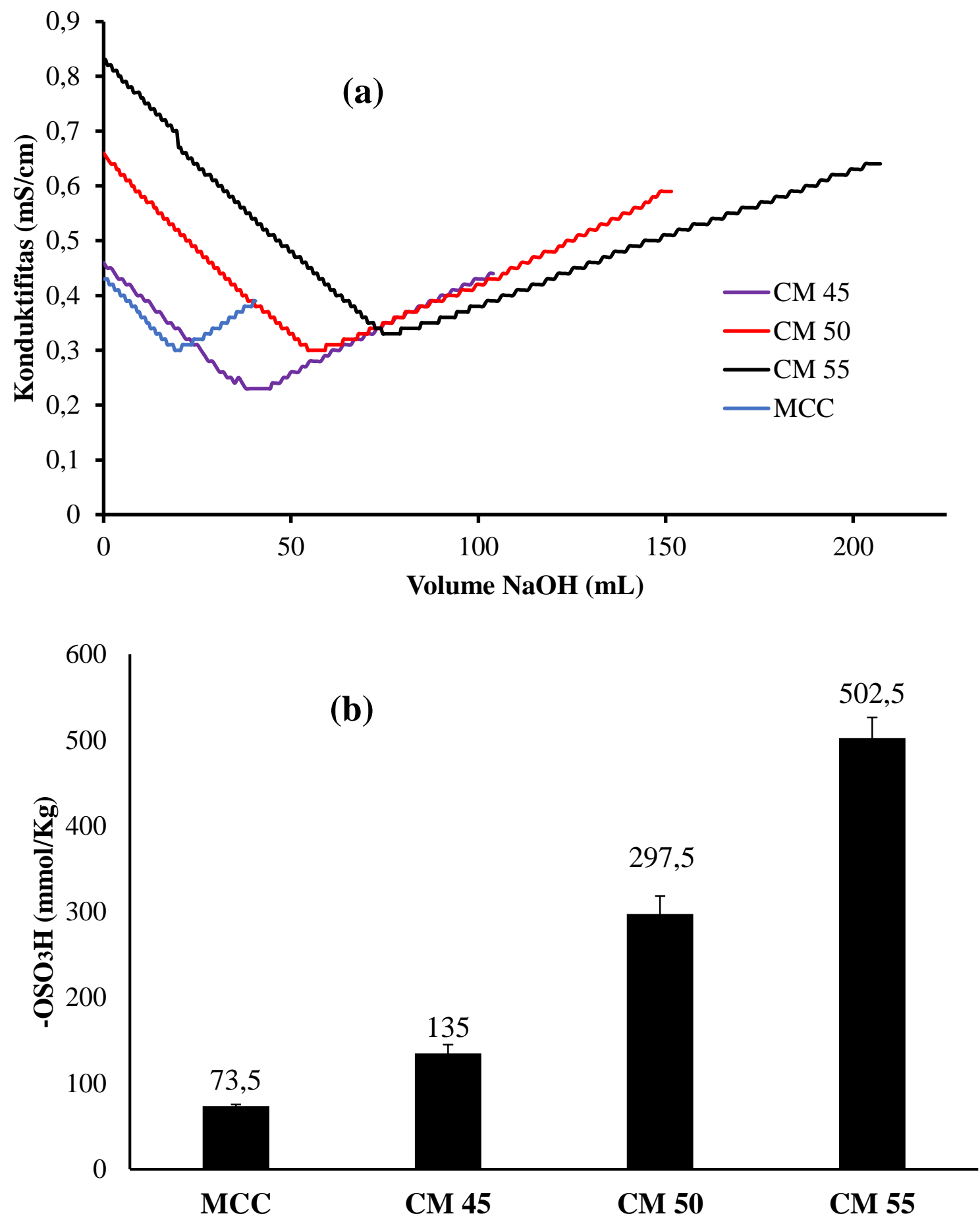

Gambar 2. (a) Kurva titrasi konduktometri dan (b) nilai jumlah gugus permukaan pada selulosa berbagai variasi konsentrasi.

\section{Analisis FTIR}

Analisis FTIR digunakan untuk mengkonfirmasi struktur gugus fungsi dari selulosa termodifikasi. Gambar 3a menunjukkan spektrum FTIR dari MCC dan CM menghasilkan serapan puncak khas gugus fungsional selulosa, yaitu penyerapan puncak pada panjang gelombang 3300-3360 $\mathrm{cm}^{-1}$ yang mewakili gugus O-H stretch, 2900-2950 cm-1 mewakili 
ikatan C-H stretch dan 1000-1100 mewakili kelompok C-O-C piranosa. Secara keseluruhan, spektrum CM memiliki kemiripan dengan spektrum MCC. Akan tetapi, jika spektrum dipersempit antara $1600-800 \mathrm{~cm}^{-1}$ seperti pada gambar $3 \mathrm{~b}$, terlihat adanya puncak serapan baru pada kisaran 1100-1200 $\mathrm{cm}^{-1}$ yang ditunjukkan tanda panah yang mewakili vibrasi gugus sulfat (Iman et al., 2016; Hidayati et al., 2009). Adanya serapan gugus sulfat ini mengindikasikan bahwa hidrolisis selulosa telah termodifikasi.

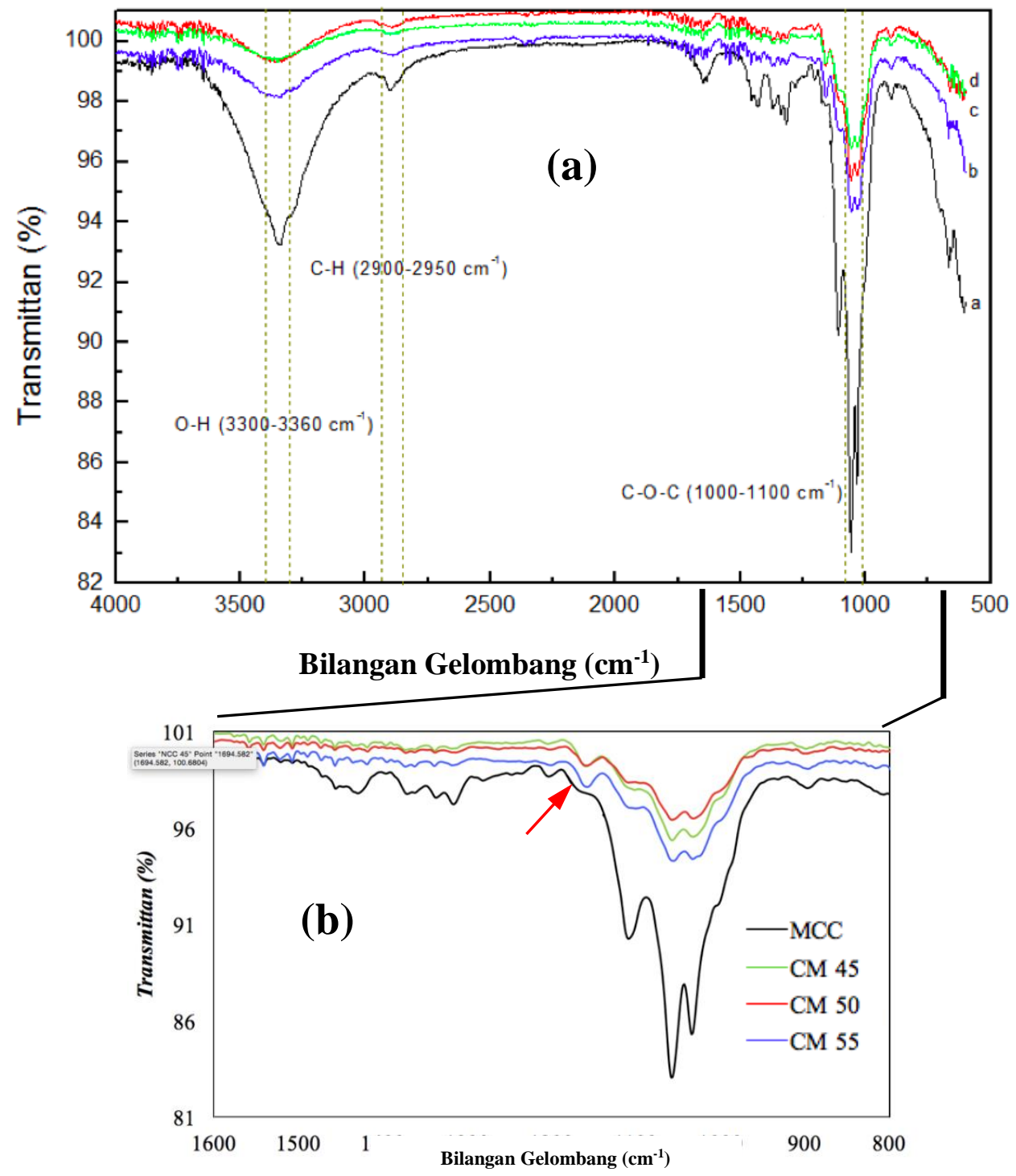

Gambar 3. Spektra FTIR pada range (a) $4000-500 \mathrm{~cm}^{-1}$ dan (b) $1600-800 \mathrm{~cm}^{-1}$.

\section{Scanning Electron Microscope (SEM)}

Analisis SEM digunakan untuk mengamati bentuk morfologi dan ukuran partikel MCC dan CM. Diameter partikel selulosa ditentukan menggunakan aplikasi image J dari hasil gambar SEM. Pada Gambar 4 dengan perbesaran 100x menunjukkan bahwa terjadi perubahan morfologi partikel dari selulosa sebelum dan sesudah dihidrolisis. Berdasarkan 
hasil analisis menunjukkan MCC terlihat berbentuk pipih dengan panjang 51,273 $\pm 10,236$ $\mu \mathrm{m}$, sementara $\mathrm{CM}$ memiliki bentuk bulat-bulat yang terdispersi dengan panjang diameter semakin kecil seiiring bertambahnya konsentrasi asam seperti pada Tabel 2.
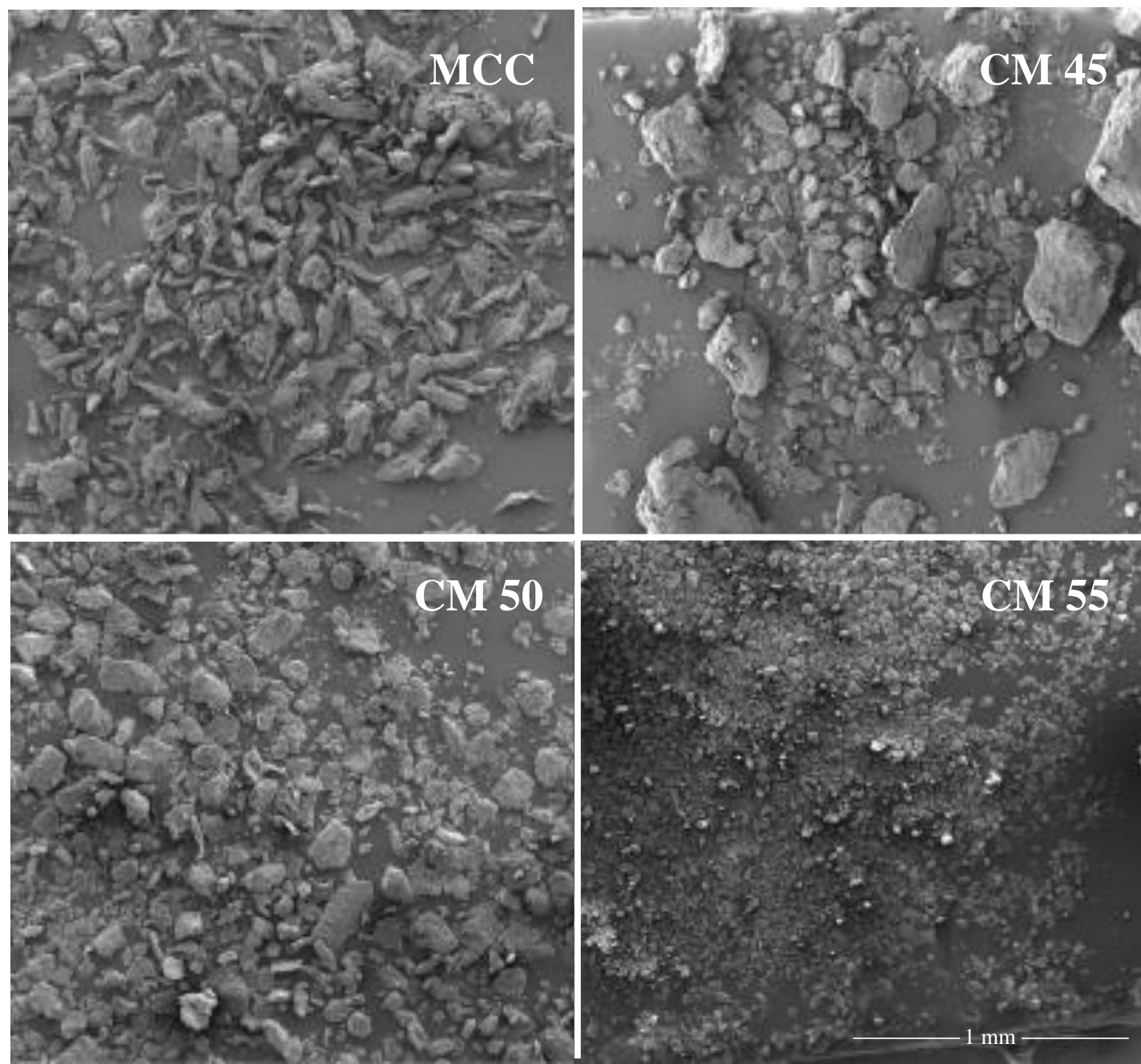

Gambar 4. Gambar hasil analisis SEM dari MCC dan CM.

Tabel 2. Ukuran distribusi partikel selulosa

\begin{tabular}{lcc}
\hline Sampel & Bentuk Partikel & Diameter $(\mu \mathrm{m})$ \\
\hline MCC & Pipih memanjang & $51,273 \pm 10,236$ \\
CM 45 & Bulat, aglomerasi & $63,472 \pm 34,352$ \\
CM 50 & Bulat, terdispersi & $46,614 \pm 14,505$ \\
CM 55 & Bulat, terdispersi & $18,742 \pm 5,255$ \\
\hline
\end{tabular}

Gambar 4 menunjukkan bahwa MCC berbentuk pipih memanjang dan teraglomerasi, sementara pada CM berbentuk bulat terdispersi kecuali pada CM45 yang terlihat masih teraglomerasi sehingga membuat ukuran rata-rata diameternya besar. Bertambahnya konsentrasi asam sulfat membuat ukuran partikel semakin kecil dan semakin terdispersi. Hal ini dikarenakan semakin banyaknya daerah amorf yang terpotong oleh asam kuat (Dong et 
al., 1998), sehingga ukuran partikelnya semakin kecil. Selain itu, adanya muatan permukaan pada CM membuat dispersitas partikelnya meningkat.

\section{Analisis XRD}

Analisis XRD digunakan untuk mengidentifikasi fasa kristalin dalam material dengan cara menentukan parameter struktur kisi serta untuk mendapatkan ukuran partikel. Karakterisasi XRD dalam penelitian ini dilakukan untuk mengetahui perbedaan kristallinitas selulosa sebelum dan sesudah dihidrolisis serta pengaruh perbedaan konsentrasi asam sulfat yang digunakan untuk hidrolisis.

(a)

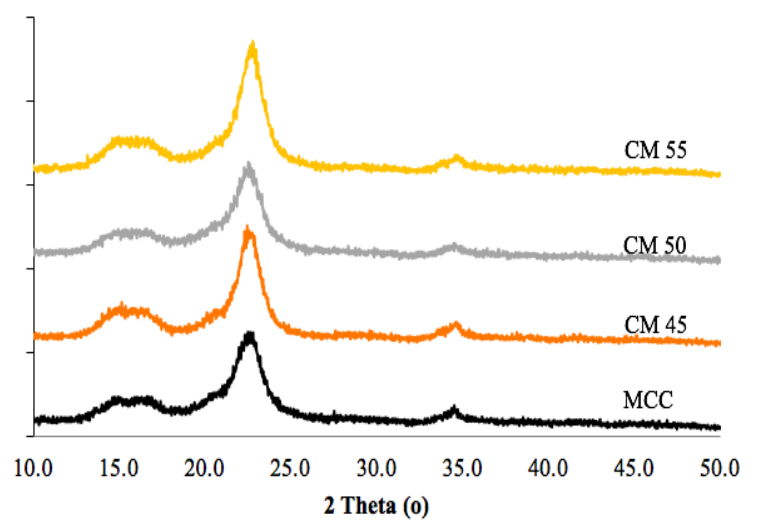

(b)

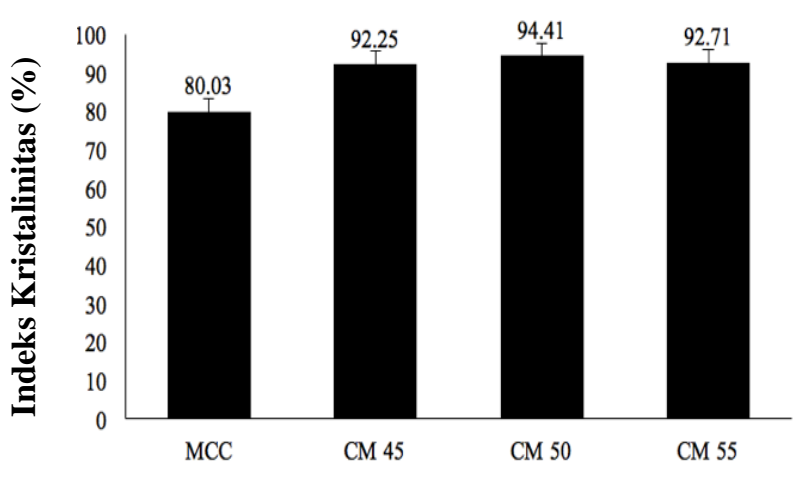

Gambar 5. (a) Hasil Pola XRD dan (b) indeks kristalinitas dari MCC dan CM.

Gambar 5a menunjukkan bahwa hasil analisis difraksi sinar-X menghasilkan puncak difraksi pada sudut $2 \theta=15 ; 16,1 ; 22,5$; dan 34,5 dimana difraksi puncak ini sesuai dengan bidang kristalografi karakteristik selulosa I $\beta$ yaitu (1-10), (110), (200) dan (004) (French, 2014). Menurut French (2014) puncak-puncak yang memiliki peran dominan dari indeks Miller hanya bidang (1-10), (110) dan (200) sementara untuk puncak di $2 \theta=34,5$ (004) merupakan puncak moderat yang dinilai lemah dan dianggap tidak ada. Sementara itu, indeks kristalinitas didapatkan dari pengukuran lebar dan tinggi intensitas pada bidang (110), yang merupakan intensitas fasa amorf dan (200), yaitu intensitas maksimum daerah kristallin pada selulosa (Maddahy et al., 2012). Berdasarkan hasil perhitungan menggunakan persamaan (1), indeks kristalinitas selulosa meningkat setelah dilakukan modifikasi dengan hidrolisis asam seperti pada gambar 5b. Indeks kristalinitas CM pada berbagai konsentrasi asam menunjukkan sedikit perbedaan, akan tetapi tertinggi terjadi pada CM 55. Kristalinitas yang tinggi karena hilangnya porsi daerah amorf pada MCC oleh serangan asam kuat (Habibi et al., 2010). 


\section{KESIMPULAN}

Hidrolisis selulosa oleh asam sulfat menyebabkan perubahan struktur selulosa sebagai masuknya gugus sulfat pada selulosa. Peningkatan konsentrasi asam sulfat pada $50 \%$ (b/b) meningkatkan indeks kristalinitas hingga 94,4\%, tetapi menurun untuk konsentrasi asam sulfat lebih lanjut. Analisis morfologi menunjukkan bahwa CM memiliki ukuran partikel yang lebih tinggi. Gugus sulfat sebagai muatan permukaan pada CM semakin meningkat dengan meningkatnya konsentrasi asam sulfat.

\section{UCAPAN TERIMA KASIH}

Penulis berterima kasih kepada seluruh pihak baik secara langsung maupun tidak langsung yang telah membantu atas selesainya penelitian ini terutama kepada Kementerian Riset, Teknologi, dan Pendidikan Tinggi atas dukungan keuangan untuk penelitian ini melalui Research Grand PUPT 2016.

\section{DAFTAR PUSTAKA}

Bondeson, D., Mathew, A., and Oksman, K., 2006. Optimization of the isolation of nanocrystals from microcrystalline cellulose by acid hydrolysis. Cellulose 13, 171. doi: 10.1007/s10570-006-9061-4.

Dong, C., Zhang, F., Pang, Z., and Yang, G., 2016. Efficient and selective adsorption of multi-metal ions using sulfonated cellulose as adsorbent. Carbohydrate polymers 151, 230-236. doi: 10.1016/j.carbpol.2016.05.066.

Dong, X. M., Revol, J., and Gray, D. G. 1998. Effect of microcrystallite preparation conditions on the formation of colloid crystals of cellulose. Cellulose 5, 19-32. doi: 10.1023/A:1009260511939.

French A.D., 2014. Idealized powder diffraction patterns for cellulose polymorphs. Cellulose 21, 885-896. doi: 10.1007/s10570-013-0030-4.

Habibi, Y., Lucia, L. A., and Rojas, O. J., 2010. Cellulose nanocrystals: chemistry, selfassembly, and applications. Chemical reviews 110, 3479-3500. doi: 10.1021/ cr900339w.

Hidayati S. 2009. Pengaruh rasio mol, suhu dan lama reaksi terhadap tegangan permukaan dan stabilitas emulsi metil estersulfonat dari CPO. Jurnal Teknologi Industri dan Hasil Pertanian 1, 38-44.

Iman, N., Rahman, A., Nurhaeni. 2016. Sintesis surfaktan metil ester sulfonat (MES) dari metil laurat. KOVALEN Jurnal Riset Kimia 2, 54-66.

Ioelovich, M. 2012. Study of cellulose interaction with concentrated solutions of sulfuric acid. ISRN Chemical Engineering 2012. doi: 10.5402/2012/428974 
Klemm, D., Kramer, F., Moritz, S., Lindstrom, T., Ankerfors, M., Gray, D., and Dorris, A., 2011. Nanocelluloses: a new family of nature-based materials. Angewandte Chemie International Edition 50, 5438-5466. doi: 10.1002/anie.201001273.

Kolakovic, R., Peltonen, L., Laukkanen, A., Hirvonen, J., and Laaksonen, T., 2012. Nanofibrillar cellulose films for controlled drug delivery. European Journal of Pharmaceutics and Biopharmaceutics 82, 308-315. doi: 10.1016/j.ejpb.2012.06.01.

Kovacs, T., Naish, V., O'Connor, B., Blaise, C., Gagné, F., Hall, L., and Martel, P. 2010. An ecotoxicological characterization of nanocrystalline cellulose (NCC). Nanotoxicology 4, 255-270. doi: 10.3109/17435391003628713.

Lee, H. V., S. B. A. Hamid, and S. K. Zain, 2014. Conversion of Lignocellulosic Biomass to Nanocellulose : Structure and Chemical Process. The Scientific World Journal, 2014. doi: 10.1155/2014/631013.

Li, W., Yue, J., and Liu, S., 2012. Preparation of nanocrystalline cellulose via ultrasound and its reinforcement capability for poly (vinyl alcohol) composites. Ultrasonics Sonochemistry 19, 479-485. doi: 10.1016/j.ultsonch.2011.11.007.

Maddahy, N. K., Ramezani, O., and Kermanian, H., 2012. Production of Nanocrystalline Cellulose from Sugarcane Bagasse, Proceedings of the 4th International Conference on Nanostructures. ICNS4. 12-14 Maret 2012, Kish Island, I. R. Iran, pp. 87-89.

Mandal, A., and Chakrabarty, D., 2011. Isolation of nanocellulose from waste sugarcane bagasse (SCB) and its characterization. Carbohydrate Polymers 86, 1291-1299. doi: 10.1016/j.carbpol.2011.06.030.

Masruchin, N., Park, B.D., Causin, V., and Um, I. C., 2015. Characteristics of TEMPOoxidized Cellulose Fibril-based Hydrogels Induced by Cationic Ions and Their Properties. Cellulose 22, 1993-2010. doi: 10.1007/s10570-015-0624-0.

Piluharto, B., Suendo, V., Ciptati, T., and Radiman, C. L., 2011. Strong correlation between membrane effective fixed charge and proton conductivity in the sulfonated polysulfone cation-exchange membranes. Ionics 17, 229-238. doi: 10.1007/s11581011-0537-3.

Putri, E., and Gea, S., 2018. Isolasi dan Karakterisasi Nanokistral Selulosa dari Tandan Sawit (Elaeis Guineensis Jack). Elkawnie 4, 13-22. doi: 10.22373/ekw.v4i1.2877.

Romdhane, A., Aurousseau, M., Guillet, A., and Mauret, E., 2015. Effect of pH and Ionic Strength on The Electrical Charge and Particle Size Distribution of Starch Nanocrystal Suspensions. Starch Journal 67, 319-327. doi : 10.1002/star.201400181.

Tian, C., Yi, J., Wu, Y., Wu, Q., Qing, Y., and Wang, L. 2016. Preparation of highly charged cellulose nanofibrils using high-pressure homogenization coupled with strong acid hydrolysis pretreatments. Carbohydrate Polymers 136, 485-492. doi: 10.1016 j.carbpol.2015.09.055.

Wulandari, W. T., Rochliadi, A., and Arcana, I. M. 2016. Nanocellulose prepared by acid hydrolysis of isolated cellulose from sugarcane bagasse. In: IOP conference series: materials science and engineering. IOP Publishing, 2016. pp. 012045.

Yu, H. Y., Qin, Z. Y., Liu, L., Yang, X. G., Zhou, Y., and Yao, J. M., 2013. Comparison of the reinforcing effects for cellulose nanocrystals obtained by sulfuric and hydrochloric acid hydrolysis on the mechanical and thermal properties of bacterial 
polyester. Composites Science and Technology 87, 22-28. doi: 10.1016/j.compscitech.2013. 07.024. 